\title{
Metonymy in Czech Word Formation in Terms of Cognitive Linguistics
}

\author{
By Božena Bednařiková* \& Zuzana Novotná ${ }^{\dagger}$
}

\begin{abstract}
Substitutional metonymy is generally considered as one of the basic conceptual processes that have the power to indirectly name the reality. The principle of the metonymy is a shift of meaning based on certain internal connections (for metonymy Kövecses and Radden 1998, Koch 1999, Peirsman and Geeraerts 2006, Langacker 2009). According to the cognitively oriented linguist Laura A. Janda, similar metonymic relationships can be identified in Czech word-formational processes (Janda 2010). The base of the study is an idea that between the vehicle and the target there is a relationship which is similar to the substitutional metonymy. The aim is to apply that perspective on the specific language material. The database of linguistic material was excerpted from two fairytales by Karel Čapek (Čapek 1972). The research has focused on nouns. The analyzed material consists of 193 nouns formed by suffixation, desuffixation, conversion (for conversion in Czech see Bednařiková 2009), as well as the combined processes. The crucial point are the analysis of metonymic relationships and the number of their occurrences in the database of nouns. The most often metonymic patterns for vehicle and target are also presented, as well as the most frequent suffixes. The analysis clearly indicates that there are verbs that have the strongest position in the word formation of nouns. Regarding the metonymic pattern the most frequent target within the database are the abstraction, entity and agent. In the end of the study there is a conclusion summarizing the main findings.
\end{abstract}

Keywords: Conversion, Metonymy, Target, Vehicle, Word formation

\section{Introduction}

The milk tipped over (Janda 2010, 2011, 2014) is a prototypical and oftencited example of metonymy. The majority of studies have focused on what is called lexical metonymy so far. The above cited example is a typical one. In lexical metonymy, the source (here the term VEHICLE is used) is associated with the word and the TARGET is the meaning that is actually accessed. Thus the shift consists of a CONTAINER that is accessed by reference to its CONTENTS. What is in fact shifted is the whole lexeme. That is the basis of the lexical, i.e., substitutional metonymy. Looking at another example, květináč ("flower-pot") one could argue that there is a relationship which is similar to the substitutional metonymy. The VEHICLE corresponds to the founding word (the source word) kvétina ("flower") and the TARGET to the word-formational affix -áč. The shift itself seems to be parallel to that of substitutional metonymy. A CONTAINER is again accessed by reference to its CONTENTS, but this time the shift is achieved by grammatical means, in this case by the morphological process of derivation using the formant $-\dot{a} c ̌-\emptyset$, where $-a ́ c ̌ c$ is the derivational suffix, and $-\varnothing$ is the inflectional suffix (desinence, ending).

The first part of the study explaines the aim of the study and the type of the research. The next section briefly outlines the theoretical background and the

*Associate Professor, University Olomouc, Czech Republic.

${ }^{\dagger}$ PhD Student, University Olomouc, Czech Republic. 
up-to-date literature. What follows next is building up the database for the research. Then the analysis of the language material is presented and discussed. The final section communicates the conclusion.

\section{The Purpose of the Research (A Case Study)}

The main purpose of the study is to break new ground for the Czech wordformational theory which would be base both on the concept of morphology as study of the inner structure of a word (Komárek 2006, Bednaříková 2009, 2017) and on cognitive linguistics. What is also intended here is to apply the classification system of word-formational metonymy elaborated by Janda (2010, 2011) on a particular language material. Janda's system is based on traditional word-formational theory as seen in Dokulil (1962) and in Dokulil et al. (1986) and parallel to Peirsman and Geeraerts (2006). The aim of the case study is a) to construct and analyse the database of nouns which were formed by either suffixation or conversion, b) to explore the most frequent metonymical relations, c) to explore the metonymical patterns and to find the central word-formational formants.

\section{Theoretical Background - a Brief Survey}

What first must be mentioned is the specifics of the Czech word-formational theory elaborated by Dokulil (1962) and by Dokulil et al. (1986). Dokulil created the onomasiological model of word-formation which consists of 4 abstract conceptual categories complying with the four basic parts of speech (word classes). The conceptual categories are: substance, quality, action and circumstance. The meaning of the coined word is based on the interrelations between them. Thus the onomasiological structure has the pattern: MARK (vehicle/source) + BASE. In the coined word hlupák ("fool, blockhead") the MARK (vehicle) is the adjective expressing the category of quality hloupý ("foolish") and the BASE (target) is the formant -ák- $\varnothing$ (derivational suffix-ending) representing the category of substance (someone who bears the quality of hloupy).

As far as the notion of metonymy is concerned it has various meanings according of various branches of scholarship. The Greek word metónymia means "renaming" that is based on the transmission of meaning. Metonymy is mainly employed in literary theory as one of the tropes, i.e., indirect naming of reality. In lexicology, it is used in the sense of multiplication of meanings, as something causing the emergence of polysemy (Dokulil 1962, Hauser 1980, Filipec and Čermák 1985). With regard to cognitive linguistics, the term metonymy is used in two senses:

a. as a shift (mapping) within a single domain (Croft 1993, Langacker 1993, 2009, Kövecses and Radden 1998, Kövecses 2002),

b. as a contiguity relationship (Jakobson and Halle 1980, Peirsman and Geeraerts 2006). 
Here the research leans upon the way in which the metonymy is handled by Janda (2010, 2011, 2014), i.e., metonymy as a referential relational between two concepts: a source (VEHICLE) concept is overtly named and provides the mental access to a TARGET concept in a given context. Similarly the notion of metonymy is understood in Kövecses and Radden (1998) as a cognitive process in which one conceptual entity (VEHICLE) provides mental access to another conceptual entity (TARGET). Thus the cognitive strategy of metonymical association uses conceptual force to access the target.

Making the best use of Dokulil's theory of onomasiological categories (Dokulil et al. 1986) and the inventory of substitutional metonymy by Peirsman and Geeraerts (2006) as well as the VEHICLE for TARGET model for classification of metonymy (Lakoff 1987) Janda designed a classification system which she used for exploring the Czech word-formational metonymy signalled by suffixation [see Dokulil's part of Mluvnice češtiny, Dokulil et al. (1986)]. Her activities aimed to demonstrate the parallels between substitutional and word-formational metonymy (Janda 2010).

\section{Database of Czech Word-Formational Metonymy}

The language material that served for our research were two fairy tales from the book by Karel Čapek (1890-1938) Devatero pohádek ("Nine fairy tales"), namely Pohádka pošt'ácká ("Postman's fairy tale") and Pohádka tulácká ("Drifter's fairy tale"). The limitations for the excerption and analysis covered the necessity to excerpt only nouns. The morphological means on the stock were only derivation (suffixation) and conversion. What was excluded were modification category, i.e., deminutives as hvězdička ("star") or augmentatives as názvisko ("title"). Excluded were also the proper names, but only as target, not as vehicle/source: Bugatti $\rightarrow$ bugatka, and hypocoristics. But not excluded were deverbal nouns as žebrat/žebrán/ $\rightarrow$ žebrání ("beg/begged/ $\rightarrow$ begging").

The size of our final corpus in the database was 193 nouns. The structure of the database consisted of the founding/source word as the VEHICLE/source, the founded/coined word as the TARGET, metonymical relation following the model: VEHICLE/SOURCE for TARGET), the morphological process of either of suffixation, or conversion, the central word-formational formant and the supporting formant as the phonological alternations, type of declension (type of the morphological "pattern" represented by the model/WORD/ generally used in Czech grammars). A short sample of the structure of the database is shown at the Table $1^{1}$.

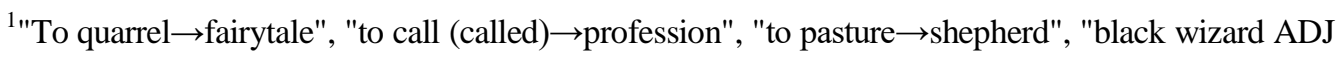
$($ or black book) $\rightarrow$ black wizard", "water (or water ADJ) $\rightarrow$ water goblin", "post office $\rightarrow$ postman", "write down $\rightarrow$ writing", "declare $\rightarrow$ public notice".
} 
Table 1. The Structure of the Database

\begin{tabular}{|c|c|c|c|}
\hline $\begin{array}{l}\text { VEHICLE } \rightarrow \\
\text { TARGET }\end{array}$ & $\begin{array}{l}\text { VEHICLE } \rightarrow \\
\text { TARGET }\end{array}$ & Process & $\begin{array}{l}\text { Central+ } \\
\text { Supporting formant }\end{array}$ \\
\hline $\begin{array}{l}\text { Pohádat } \rightarrow \\
\text { pohádka }\end{array}$ & $\begin{array}{l}\text { ACTION } \rightarrow \\
\text { PRODUCT }\end{array}$ & suffixation & $-\mathrm{k}-\mathrm{a}+/ \mathrm{ŽENA} /$ \\
\hline $\begin{array}{l}\text { povolat } \\
\text { (povolán) } \rightarrow \\
\text { povolání } \\
\end{array}$ & $\begin{array}{l}\text { ACTION } \rightarrow \\
\text { ABSTRACTION }\end{array}$ & conversion & -1́/STAVENÍ/+n ň \\
\hline $\begin{array}{l}\text { pást } \rightarrow \\
\text { pastýr }\end{array}$ & $\begin{array}{l}\text { ACTION } \rightarrow \\
\text { AGENT }\end{array}$ & suffixation & -(t)ýřr-Ø+á a/MUŽ/ \\
\hline $\begin{array}{l}\text { černokněžný (or } \\
\text { černá kniha) } \rightarrow \\
\text { černokněžník }\end{array}$ & $\begin{array}{l}\text { CHARACTERISTIC } \rightarrow \\
\text { ENTITY }\end{array}$ & $\begin{array}{l}\text { (composition+) } \\
\text { suffixation }\end{array}$ & -(n)ík-Ø+i ě/PÁN/ \\
\hline $\begin{array}{l}\text { voda (or } \\
\text { vodní) } \rightarrow \\
\text { vodník }\end{array}$ & $\begin{array}{l}\text { LOCATION } \rightarrow \\
\text { LOCATED or } \\
\text { CHARACTERISTIC } \rightarrow \\
\text { ENTITY }\end{array}$ & suffixation & -ník-Ø+/PÁN/ \\
\hline $\begin{array}{l}\text { pošta } \rightarrow \\
\text { pošt'ák }\end{array}$ & $\begin{array}{l}\text { LOCATION } \rightarrow \\
\text { LOCATED }\end{array}$ & suffixation & -ák-Ø+t t’+PÁN/ $^{\prime}$ \\
\hline $\begin{array}{l}\text { napsat } \rightarrow \\
\text { nápis }\end{array}$ & $\begin{array}{l}\text { ACTION } \rightarrow \\
\text { PRODUCT }\end{array}$ & conversion & -Ø/HRAD/+a á \\
\hline $\begin{array}{l}\text { vyhlásit } \rightarrow \\
\text { vyhláśka }\end{array}$ & $\begin{array}{l}\text { ACTION } \rightarrow \\
\text { PRODUCT }\end{array}$ & suffixation & $-\mathrm{k}-\mathrm{a}+\mathrm{s} \sim \check{\mathrm{s}} / \mathrm{Z} \mathrm{ENA} /$ \\
\hline
\end{tabular}

As far as classification of the language material, i.e., the metonymical excerpts, is concerned, one has to face a couple of limitations which often appear to be interesting challenges.

a) The first one concerns identification of the VEHICLE/source: As seen in Table 1 the word vodnik ("water goblin") may have two interpretations concerning its VEHICLE. It can be either the noun voda ("water"), or the adjective vodni ("water, of water, aquatic"). This may result in different metonymical relations. If the founding word interpretation leads to the noun voda, then the slot for VEHICLE in the general metonymical relation VEHICLE $\rightarrow$ TARGET is occupied by LOCATION and the TARGET by LOCATED. In the latter case, that is with the adjective vodni as the founding word, the VEHICLE is occupied by CHARACTERISTIC and the TARGET by ENTITY. The decision (here both solutions) leans upon Dokulil's word-formational theory.

b) Another limitation to deal with is the fact that a VEHICLE may serve for two TARGETS, formally quite homomorphous. A good example may be the verb psát ("write"). By applying the word-formational process of conversion namely using the past participle psán ("written") for substantivization we may have two different words psani and with that, of course, two different metonymical relations: either ACTION for ABSTRACTION ("the process of writing"), or ACTION for PRODUCT ("a letter as a result of writing, as something what has been written"). Understanding the respective meaning is obviously context bounded. At the same time one can think of the process of concretization of the abstracts (here the result of the action is a respective noun).

c) What should not be omitted is the context boundedness: as partly seen in the previous paragraph the context boundedness may play a crucial role in interpreting the metonymical relation. The noun vrták ("drill") as a coined word with the word-formational pattern vrtat $\rightarrow$ vrták ("to drill $\rightarrow$ the drill") can be seen as a TOOL, though in the case of the analyzed text (a fairy tale) it bears a 
metonymic meaning of ENTITY, since it is expressively used in relation to a person, i.e., "one who screwed up something, clumsy, lubber". In these cases it is the context and the updated meaning of the word in the text that decide.

d) What also should be handled is the question of interpretation of the wordformational formant: A good example may be nouns as nádiva, nezdoba ("stuffed, not ornamented"). Even if there is a detachable segment in the end of the words, i.e., $-a$, it is not a word-formational suffix, but a grammatical suffix of nominative singular. Both words are word-formationally the result of conversion nadivat $s e \rightarrow$ nádiva, nezdobit $\rightarrow$ nezdoba ("to stuff $\rightarrow$ the stuffed, not to ornament $\rightarrow$ the not ornamented"), both following the metonymical relation ACTION $\rightarrow$ AGENT. The central word-formational formant is the change of inflection, that means that here the conjugation of the original verb was replaced by declension of the newly formed noun. Thus the segment $-a$ in the end of the noun is not a wordformational suffix, but the representative of the whole inflectional paradigm, usually represented by the inflectional pattern PŘEDSEDA.

\section{Analysis of Metonymical Relations}

The database of excerpted language material in this research contains 193 nouns, which were subsequently subdivided according to individual metonymical relations, suffixes, and conversion types. Further research focuses primarily on the number of words (occurrences) in each category of metonymic relationships, the number of words within individual suffixes or types of conversions, as well as on what metonymical pattern and what part of speech prevail in the VEHICLE/source and the TARGET. Altogether 33 kinds of metonymical relationships were identified in the language material database. The "top ten" metonymical relations according to the number of items are shown in Table $2^{2}$.

As evidenced by Table 2, the most commonly identified metonymical relationship is the ACTION for ABSTRACTION. In the context of analyzed nouns, the ACTION was most often used to point to a specific ABSTRACTION. There are 43 nouns in this category, but only eight of them are derivatives. Although it is the strongest model, it is associated only with three derivational suffixes. Thus within this category three suffixes have been identified, namely $b(a), \quad-o s t-\emptyset$ and $-e-\emptyset$ (sloužit $\rightarrow$ služba, litovat $\rightarrow$ litost, loupit $\rightarrow$ loupež, "to serve $\rightarrow$ service, to regret $\rightarrow$ regret, to rob $\rightarrow$ robbery"). Even if the number of words in this metonymical category is the highest, the number of suffixes is comparatively small compared to other categories. All other words within this metonymical relationship have been created by word-formational process of conversion (type verb $\rightarrow$ noun); for example prekvapit/překvapen/ $\rightarrow$ překvapení,

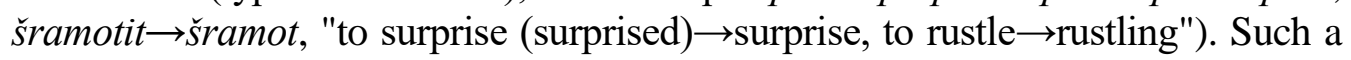
large number of words resulting from conversion can be attributed to the fact that our analysis also includes verbal nouns. Indeed, all these nouns belong to that particular metonymical relationship.

\footnotetext{
2 "to serve $\rightarrow$ service", "to surprise (surprised) $\rightarrow$ surprise", "good $\rightarrow$ good guy", "to guard $\rightarrow$ constable", "to produce $\rightarrow$ product", "quick $\rightarrow$ quickness", "to toddle $\rightarrow$ novice", "to connect $\rightarrow$ connector", "mill $\rightarrow$ miller", "king $\rightarrow$ kingdom", "to consume $\rightarrow$ foodstuff".
} 
The second most common metonymical relationship is the CHARACTERISTIC for THE ENTITY, in which a total of 24 nouns were identified. Within this category, 19 nouns were created by the word-formational process of derivation (15 nouns were created by suffixing-dobrý $\rightarrow$ dobrák ("good $\rightarrow$ good man"), four nouns by desuffixation-darebny $\rightarrow$ dareba, "roguish $\rightarrow$ rogue"). The model is associated with eight derivational suffixes: -ic-e, -ák- $\emptyset$, -ník- $\emptyset$, -ek- $\emptyset,-e c-\emptyset$, enec- $\emptyset$, -ik- $\emptyset$, -och- $\emptyset$. The remaining five words were created by conversion, namely the adjective $\rightarrow$ noun type: $m u z ̌ s k y ́ /$ adj./ $\rightarrow$ mužský/noun/("male $\rightarrow$ man").

The third most frequent metonymical model is the ACTION for AGENT (strážit $\rightarrow$ strážnik, stvořit $\rightarrow$ stvoritel, "to guard $\rightarrow$ constable, to create $\rightarrow$ creator"). In this category, 23 nouns were identified, 14 of which were formed by suffixing and nine by conversion (type verbum $\rightarrow$ noun, nadivat $s e \rightarrow$ nádiva. In this category, a total of ten suffixes have been found, namely -ník- $\emptyset$, -tel- $\emptyset,-a ́ k-\emptyset,-\check{c}-\emptyset,-\check{c}-i$, , ek$\emptyset,-i k-\emptyset,-/ t y_{\grave{r}}-\emptyset,-c-e,-$ ouch $\emptyset$.

Table 2. The "Top Ten" Metonymical Relations

\begin{tabular}{|l|l|c|l|}
\hline 1 & ACTION $\rightarrow$ ABSTRACTION & 42 & $\begin{array}{l}\text { sloužit } \rightarrow \text { služba } \\
\text { ("to serve } \rightarrow \text { service") } \\
\text { překvapit (překvapen) } \rightarrow \text { překvapení } \\
\text { ("to surprise (surprised) } \rightarrow \text { surprise") }\end{array}$ \\
\hline 2 & CHARACTERISTIC $\rightarrow$ ENTITY & 24 & $\begin{array}{l}\text { dobrý } \rightarrow \text { dobrák } \\
\text { ("good } \rightarrow \text { good guy") }\end{array}$ \\
\hline 3 & ACTION $\rightarrow$ AGENT & 23 & $\begin{array}{l}\text { strážit } \rightarrow \text { strážník } \\
\text { ("to guard } \rightarrow \text { constable") }\end{array}$ \\
\hline 4 & ACTION $\rightarrow$ PRODUCT & 14 & $\begin{array}{l}\text { vyrobit } \rightarrow \text { výrobek } \\
\text { ("to produce } \rightarrow \text { product") }\end{array}$ \\
\hline 5 & CHARACTERISTIC $\rightarrow$ ABSTRACTION & 11 & $\begin{array}{l}\text { rychlý } \rightarrow \text { rychlost } \\
\text { ("quick } \rightarrow \text { quickness") }\end{array}$ \\
\hline 6 & ACTION $\rightarrow$ ENTITY & 8 & $\begin{array}{l}\text { capat } \rightarrow \text { cápek } \\
\text { ("to toddle } \rightarrow \text { novice") }\end{array}$ \\
\hline 7 & ACTION $\rightarrow$ INSTRUMENT & 8 & $\begin{array}{l}\text { spojit } \rightarrow \text { spojka } \\
\text { ("to connect } \rightarrow \text { connector") }\end{array}$ \\
\hline 8 & LOCATION $\rightarrow$ LOCATED & 7 & $\begin{array}{l}\text { mlýn } \rightarrow \text { mlynáŕ } \\
\text { ("mill } \rightarrow \text { miller") }\end{array}$ \\
\hline 9 & LOCATED $\rightarrow$ LOCATION & 6 & $\begin{array}{l}\text { král } \rightarrow \text { království } \\
\text { ("king } \rightarrow \text { kingdom") }\end{array}$ \\
\hline 10 & ACTION $\rightarrow$ PATIENT & 6 & $\begin{array}{l}\text { požíivat } \rightarrow \text { poživatina } \\
\text { ("to consume } \rightarrow \text { foodstuff") }\end{array}$ \\
\hline
\end{tabular}

\section{Analysis of VEHICLE/SOURCE}

The analysis shows that the most common type of VEHICLE is ACTION: stvořit $\rightarrow$ stvořitel, vyhlásit $\rightarrow$ vyhláška ("to create $\rightarrow$ creator, to declare $\rightarrow$ decree"). ACTION as a VEHICLE has been found in eight categories of metonymical relationship, and generally appears in 106 words. The most frequent part of speech for ACTION is, as can be expected, the verb. Nevertheless, verbs may also correspond to the metonymical model of STATE if it is a verb expressing state (ex. stát $\rightarrow$ stanice, čekat $\rightarrow$ čekání, "to stand $\rightarrow$ station, to wait $\rightarrow$ waiting"). Consequently, the verb appeared as VEHICLE (and the founding word) in 110 words from the database, and is thus the most common part of speech expressing the VEHICLE. 
The second most common type of VEHICLE is CHARACTERISTIC (mrňavý $\rightarrow$ mrňavec, rychlý $\rightarrow$ rychlost, "tiny $\rightarrow$ tot, quick $\rightarrow$ quickness"). It was identified in five categories of metonymical relationships. CHARACTERISTIC appears as VEHICLE in 39 words, so the number of words exactly matches the number of adjectives. Nevertheless, the adjectives do not correspond to the second most common part of speech for the VEHICLE, because all other metonymical patterns (LOCATION, ABSTRACTION, LOCATION, etc.) correspond to nouns. The total sum of nouns was 40, i.e., one more than the adjectives. Table 3 shows all the metonymical patterns for VEHICLE/SOURCE.

Table 3. Analysis of VEHICLE/Source

\begin{tabular}{|l|c|}
\hline VEHICLE/SOURCE (metonymical patterns) & Number of words \\
\hline ACTION & 106 \\
\hline CHARACTERISTIC & 39 \\
\hline LOCATION & 8 \\
\hline ABSTRACTION & 7 \\
\hline LOCATED & 6 \\
\hline PATIENT & 4 \\
\hline QUANTITY & 4 \\
\hline ENTITY & 3 \\
\hline STATE & 3 \\
\hline PRODUCT & 3 \\
\hline GROUP & 3 \\
\hline AGENT & 2 \\
\hline MATERIAL & 2 \\
\hline CONTENT & 1 \\
\hline WHOLE & 1 \\
\hline PART & 1 \\
\hline
\end{tabular}

Analysis of TARGET

Table 4 shows how many TARGETS (in founded words) were identified within the metonymical patterns. The three most common TARGETS are then commented in more detail.

Table 4. Analysis of TARGET

\begin{tabular}{|l|c|}
\hline TARGET (metonymical patterns) & Number of words \\
\hline ABSTRACTION & 58 \\
\hline ENTITY & 43 \\
\hline AGENT & 34 \\
\hline PRODUCT & 14 \\
\hline LOCATION & 13 \\
\hline INSTRUMENT & 9 \\
\hline LOCATED & 7 \\
\hline PATIENT & 7 \\
\hline EVENT & 4 \\
\hline GROUP & 1 \\
\hline CONTAINER & 1 \\
\hline WHOLE & 1 \\
\hline PART & 1 \\
\hline
\end{tabular}


It is clear from the table that the most common TARGET is ABSTRACTION, followed by ENTITY and AGENT. If we compare the results with the previous analysis of the VEHICLE, it is clear that the difference between the first and the second position in TARGET is not as evident as the difference between the first and the second position as was the case with the VEHICLE.

Again, it is necessary to mention that the higher number of TARGETS included in the ABSTRACTION is likely to be the result of the inclusion of deverbal nouns (created by conversion). Of the suffixes, then the suffix -ost- $\varnothing$ (nine occurrences) is most involved in the formation of the ABSTRACTION, then $-b-a$ (four occurrences), $-e \check{z}-\varnothing$ (two occurences) and - $e k-\emptyset$ (two occurrences). Of the total number of ABSTRACTIONS, there are 20 words derived (suffixed or formed by the combination or prefixation and suffixation), the remaining 38 words being created by conversion. For converted words, the most common type of conversion is verb $\rightarrow$ noun (36 words).

The second most common TARGET is ENTITY, the formation of which consists of 11 suffixes. The most ENTITIES were formed by the suffix $-k-a$

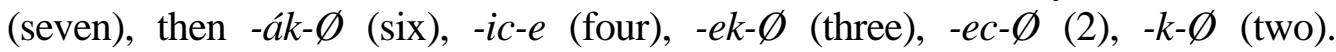
Altogether, 34 nouns were formed by derivation, the remaining nine were formed by conversion (five by the type adjective $\rightarrow$ noun, four by the type verb $\rightarrow$ noun).

The AGENT was the third most common TARGET, with a high number of suffixes (a total of 15) and one type of conversion. For the AGENT the following suffixes have been identified: -ník- $\emptyset$ (five), -ák- $\emptyset$ (three), -ár̆ $\varnothing$ (3), -tel- $\varnothing$ (two), -č- $\varnothing$ (two). Only one occurrence appears within the following

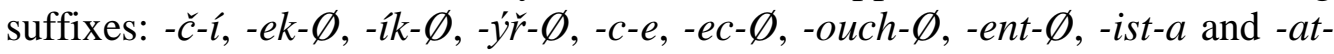
$\emptyset$. Thus 25 nouns were formed by suffixing, with the remaining nine formed by conversion of the type verb $\rightarrow$ noun.

\section{Analysis of the Central Word-Formational Formant}

A total of 126 nouns formed by the word-formational process of derivation were found in the database of language material. A total amount of 36 suffixes have been identified of which the most productive appeared $-k-a$ (17), cf. spojka, vyhláška ("connector, decree"), employed in eight metonymical relations. The second most productive suffix, found in 13 nouns, is sufix -ák- $\emptyset$, cf. tulák, chudák ("drifter, poor man"). In total, nine metonymical relationships have been identified with this suffix. Even though this suffix was identified with fewer words than the suffix $-k(a)$, the diversity of its metonymical relationships is slightly higher. The suffix -ník- $\emptyset$ has been found in 11 nouns, serving primarily for the expression of LOCATED (e.g., vodník, "water goblin"), AGENT (loupežník, "robber") and ENTITY (četník, "policeman"). In this suffix, six metonymical relationships were distinguished.

In this research we worked with live texts, and therefore, necessarily, all of the existing suffixes for forming nouns are unlikely to appear ${ }^{3}$. In addition, we

\footnotetext{
${ }^{3}$ Janda identified 207 suffixes in her study (Janda 2010). She worked with artificially created linguistic material to try to capture all words resulting from suffixing (including conversion as Janda considers this type of word-formational process as a kind of suffixation).
} 
differentiate between suffixation and conversion as different word-forming processes, and we comment on them separately.

In the language material database, a total of 67 words formed by conversion were identified. To be more specific, here is a table that lists the identified conversion types (Table 5).

Table 5. Types of Conversion

\begin{tabular}{|l|c|}
\hline Type of conversion & Number of words \\
\hline verb $\rightarrow$ noun & 58 \\
\hline adjective $\rightarrow$ noun & 6 \\
\hline noun $\rightarrow$ noun & 3 \\
\hline
\end{tabular}

For verb $\rightarrow$ noun conversion, there was a total of six categories of metonymic relationships, most often ACTON for ABSTRACTION (35 nouns; porušit (porušen $) \rightarrow$ porušení, "break (broken) $\rightarrow$ breach"). The most productive central word-formational formant in the metonymical relationship ACTION for ABSTRACTION is the declension type represented by the pattern -i (STAVENÍ). Significantly less productive is the adjective $\rightarrow$ noun type of conversion where only two categories of metonymical relationship have been identified, namely CHARACTERISTIC for ENTITY (cestujicí adj. $\rightarrow$ cestujicí noun, "travelling $\rightarrow$ traveller") and CHARACTERISTIC for ABSTRACTION (horký adj. $\rightarrow$ horko noun, "hot $\rightarrow$ heat"). In these cases, the adjectives were substantivized and there were the following central word-formational formants represented by the declension types of -í (PRU゚VODČÍ), $-\hat{y}$ (HAJNÝ), and -o (MĚSTO). The noun $\rightarrow$ noun type of conversion was always combined with prefixation, i.e., with prefixes prí- or ná-. The conversion occupied the declension type -í (STAVENÍ), see střecha $\rightarrow$ prístřeší, město $\rightarrow$ náméstí ("roof $\rightarrow$ shelter, town $\rightarrow$ square").

\section{Conclusion}

The purpose of the case study was to support the debate on relationship between metonymy and word-formation by application of Janda's classification system (2010, 2011, 2014). Janda (2010) created a systematic study dealing with the role of metonymy in Czech word formation. She worked with an artificial language material excerpted from the Czech grammars, and tried to capture all the words formed suffixation. On the contrary, our research worked with live text, and aimed to apply Janda's classification system on a particular language material. The theoretical background leaned upon the theory of metonymy as cognitive strategy using a conceptual VEHICLE/source to access a TARGET through word-formation. The robust impetus for conducting the research was Jandas call for more thorough studies of this issue (Janda 2014). The core premise here is that suffixal word-formation can be motivated by the general cognitive strategy of metonymic association. The database of Czech wordformational metonymy supplied a vivid, realistic language material through 
which the metonymical relations were identified ${ }^{4}$. The findings resting on a solid database show the VEHICLE/source-TARGET patterns are realized not only via suffixation as the type of derivation (i.e., affixal word-formation), but also via conversion (i.e., non affixal word-formation where a mere change in morphological characteristics possesses the word-forming power). The strongest metonymical relations appeared to be:

- ACTION for ABSTRACTION;

- CHARACTERISTIC for ENTITY;

- ACTION for AGENT.

The strongest metonymical patterns for VEHICLE/source were:

\section{ACTION, ABSTRACTION.}

The strongest metonymical patterns for TARGET were:

\section{ABSTRACTION, ENTITY, AGENT.}

As far as the central word-formational formant is concerned, the strongest one appeared to be suffixation (126 nouns, the most productive being the suffixes $-k-a,-a ́ k-\emptyset$, -ník- $\emptyset$, -ost- $\emptyset$, -ek- $\emptyset$. Conversion was applied with 67 words of which 58 words were formed by verb $\rightarrow$ noun type of conversion. Interpretation of the results shows that the strongest metonymical relations are:

\section{ACTION for ABSTRACTION; ACTION for AGENT.}

The above mentioned respective findings support the metonymical classification elaborated by Janda (2010). What appears to be the most interesting result is the frequency of the verbal actions. ACTION is the most widespread VEHICLE/source: it appears in eight metonymical relations and 107 nouns, while verbs are the most frequent part of speech (word class) for VEHICLE/ source. Thus the verbal ACTIONS are the most salient in Czech word-formation. There may be two sources for explanation: a) employing of conversion as an important word-formational process, b) the type of narrative as the source of language material, i.e., the fairy tales.

What the results of the analysis also show is that the outcomes seem to point to trends in mental concepts of human beings, namely to ACTION: it plays a leading role in facilitating access to many other concepts (PARTICIPANT, ABSTRACTION, INSTRUMENT, and EVENT).

\footnotetext{
${ }^{4}$ These are the conclusions of the case study, so we did not use sophisticated statistical methods.
} 


\section{Acknowledgments}

The contribution was created with the support of the Czech Ministry of Education, Youth and Sports, grant project IGA_FF_2018_025: "Czech Studies: Modern Philology in the $21^{\text {st }}$ Century". We thank all anonymous reviewers for their careful reading of our manuscript and for their inspiring comments and suggestions.

\section{References}

Bednaříková B (2009) Slovo a jeho konverze (Word and its conversion), $1^{\text {st }}$ Ed. Olomouc: Palacky University in Olomouc.

Bednař́ková B (2017) Slovo a jeho struktura (Word and its structure), ${ }^{\text {st }}$ Ed. Olomouc: Faculty of Arts of Palacký University in Olomouc.

Croft W (1993) The role of domains in the interpretation of metaphors and metonymies. Cognitive Linguistics 4(4): 335-370.

Čapek K (1972) Devatero pohádek a ještě jedna jako př́važek od Josefa Čapka (Nine fairy tales and one more as an addition from Josef Capek), $4^{\text {th }} \mathrm{Ed}$. Prague: Albatros.

Dokulil M (1962) Tvořeni slov v češtině 1. Teorie odvozování slov (Word formation in Czech 1. Word derivation theory), $1^{\text {st }}$ Ed. Prague: Academia.

Dokulil M, Horálek K, Hůrková J, Knappová M (Eds.) (1986) Mluvnice češtiny 1: Fonetika-Fonologie-Morfologie a morfemika-Tvořeni slov (Grammar of Czech 1: Phonetics-Phonology-Morphology and Morphemics-Word Formation), $1^{\text {st }}$ Ed. Prague: Academia.

Filipec J, Čermák F (1985) Česká lexikologie (Czech lexicology), $1^{\text {st }}$ Ed. Prague: Academia.

Hauser P (1980) Nauka o slovní zásobě: Učebnice pro vys. Školy (Vocabulary: Textbook for Higher Vocabulary school), $1^{\text {st }}$ Ed. Prague: SPN.

Jakobson R, Halle M (1980) Fundamentals of Language. Hague, Paris, New York: Mouton Publishers.

Janda LA (2010) The role of metonymy in Czech word-formation. Slovo a slovesnost 71(4): 260-274.

Janda LA (2011) Metonymy in word-formation. Cognitive Linguistics 22: 359-392.

Janda LA (2014) Metonymy and word-formation revisited. Cognitive Linguistics 25: 341-349.

Koch P (1999) On the cognitive bases of metonymy and certain types of word formation. In Metonymy in Language and Thought, pp. 139-167. Philadelphia: John Benjamins.

Komárek M (2006) Př́spěvky $k$ české morfologii (Contributions to Czech morphology), $2^{\text {nd }}$ Ed. Prague: Periplum.

Kövecses Z, Radden G (1998) Metonymy: Developing a cognitive linguistic view. Cognitive Linguistics 9: 37-77.

Kövecses Z (2002) Metaphor: A practical introduction, $1^{\text {st }}$ Ed. Oxford: Oxford University Press.

Lakoff G (1987) Women, fire and dangerous things: what categories reveal about the mind, $1^{\text {st }}$ Ed. Chicago: University of Chicago Press.

Langacker RW (1993) Reference-point constructions. Cognitive Linguistics 4(1): 1-38.

Langacker RW (2009) Metonymic grammar. In Metonymy and Metaphor in Grammar, pp. 45-71. Philadelphia: John Benjamins.

Peirsman Y, Geeraerts D (2006) Metonymy as a prototypical category. Cognitive Linguistics 17: 269-316. 
